\title{
70 years of the Faculty of Mining, Safety Engineering, and Industrial Automation of the Silesian University of Technology in Gliwice, Poland
}

\begin{abstract}
On July $12^{\text {th }}, 1950$, in accordance with the Regulation of the Minister of Higher Education, the Faculty of Mining was established at the Silesian University of Technology in Gliwice. Defining its tasks and curricula, recruiting staff, attracting students, and work related to the preparation of new rooms and expansion of infrastructure were the first challenges for the newly created Faculty. Over time, the name of the Faculty has also evolved, and the Faculty of Mining, Safety Engineering and Industrial Automation has been in use since 2019.
\end{abstract}

Key words: Faculty of Mining, Safety Engineering and Industrial Automation, Gliwice

\section{INTRODUCTION}

In accordance with the Regulation of the Minister of Higher Education and Science of July $12^{\text {th }}$, 1950 on organisational changes in some universities, on the basis of the decree of October $28^{\text {th }}, 1947$ on the organisation of science and higher education, the Faculty of Mining was established at the Silesian University of Technology in Gliwice in 1950 (Fig. 1).

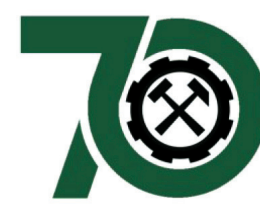

70 lat WYDZIALU GÓRNICTWA, INŻYNIERII BEZPIECZEŃSTWA I AUTOMATYKI PRZEMYStOWEJ

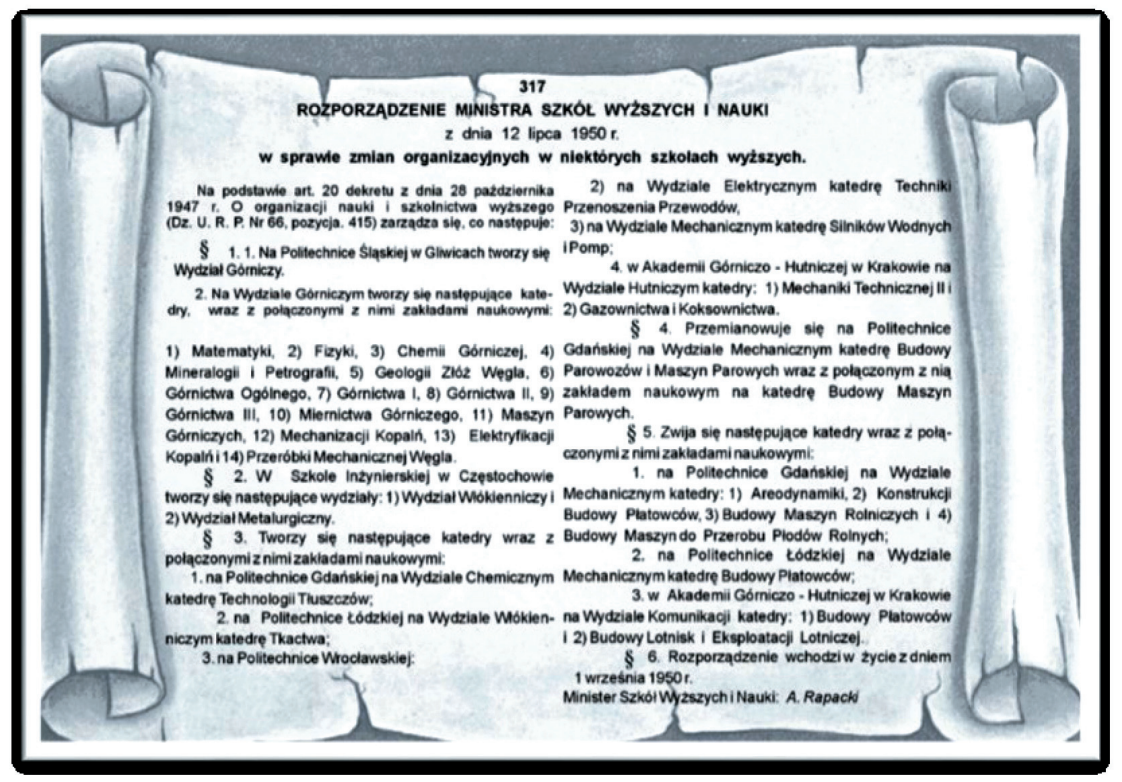

Fig. 1. Regulation of the Minister of Higher Education and Science on the establishment of the Faculty of Mining of July $12^{\text {th }}, 1950$ 
The establishment of the Faculty, and thus mining studies, was contingent on the definition of tasks and curricula for all years of education. On this basis, the teaching load was proposed for individual internal units of the Faculty, which at the time consisted of chairs and departments. This required the coordination of the mining studies program at the Silesian University of Technology with the programs of the AGH University of Science and Technology and the Wrocław University of Technology, where a Faculty of Mining specialised in the exploitation of brown coal deposits was to be established. For this purpose, the Program Studies Committee was created which defined the framework and detailed the programs of engineering studies at the Faculties of Mining. Thus, in mid-June 1950, the basis was obtained for the Rector of the Silesian University of Technology to request the Minister to establish Mining Studies at the Silesian University of Technology [1].

\section{HISTORY OF THE FACULTY}

The Founding Act of the Faculty was signed on July $12^{\text {th }}, 1950$. The preparation of the act took four months, but the Ministry sped up the proceedings and, before the administrative procedures were completed, it was agreed to establish the Dean's Office of the Faculty of Mining on July $1^{\text {st }}, 1950$ and to entrust the function of acting Dean of the Faculty to prof. Józef Wąsowski.

The key challenge, however, was to attract students and staff for the Faculty. The academic authorities, in cooperation with student organisations and with the Vocational Education Department of the Ministry of Mining, organised a free "General Mining" course for students and employees of the Silesian University of Technology who were to become potential employees of the newly created faculty in the future. The course started on July $10^{\text {th }}$ with the inaugural lecture Mining in Poland. The Geology of the Polish Coal Basins and lasted until July $19^{\text {th }}$, including lectures, seminars, and practical classes in mining.

The acquisition of the academic staff was gradual, along with the increase in the number of didactic classes. It was not until 1954-1956 that the Faculty entered its previously defined mode of operation. The Dean at that time was prof. Roman Dykacz. Over $70 \%$ of the positions of heads of chairs were taken by alumni of the AGH University of Science and Technology, but one cannot ignore the ties with the
Jagiellonian University, where the first professor of mineralogy and petrography was Jan Kühl.

Simultaneously with the commencement of the teaching activities of the Faculty, organisational work was carried out to include groups of student mining specialisations, educated at the Faculties of Mechanical and Electrical Engineering, in the structure of the Faculty of Mining. Ultimately, the students of these faculties were transferred to the Faculty of Mining in the 1951/52 academic year. In 1951, the defence of the first doctoral dissertation by Ph.D. Czesław Poborski was held at the Faculty.

It was decided to erect the building of the Faculty of Mining in a location where 50 years earlier there had been a large water reservoir - a pond, a remnant of the backwaters of the nearby Kłodnica river. The faculty was constructed on several hundred reinforced concrete piles (Fig. 2 and 3).

It was essential for the functioning of the Faculty's structure to obtain premises where it would be housed. In July 1950, the Ministry of Mining handed over the building located in the Market Square in Gliwice, where the Dean's Office of the Faculty of Mining and the Student House were established. In December 1952, the first two segments of the newly established Faculty of Mining at Plac Krakowski were made available to students and staff. The period of intensive expansion of the present seat of the Faculty took place in the years 1952-1955, which was related to the demand of the ministry of mining for highly qualified engineering staff. This resulted in the establishment of first-degree extramural studies in 1954, and evening vocational studies in 1955 . The rank of the Faculty was systematically increasing, so that in 1958 the Ministry of Mining, organising the International Mine Construction Exhibition, located it at the Faculty of Mining. In 1959, the Faculty's technology hall was put into operation.

Further activities aimed at the development of the Faculty were related to the establishment of its two branches, in Rybnik and Dąbrowa Górnicza.

At the beginning of its operation, the Faculty was made up of 17 chairs. In the 1960s/70s there were 19, while the reorganisation of the Faculty's structure in 1969 led to the creation of 8 chairs as large research and teaching units composed of previous smaller chairs. Two of them, i.e., the Chair of Mathematics C and the Chair of General Chemistry, were separated from the Faculty. In 1972, another reorganisation took place which reduced the number of chairs to 6 . These in turn gave rise to 7 research and teaching institutes. Currently, there are 6 chairs at the Faculty. 


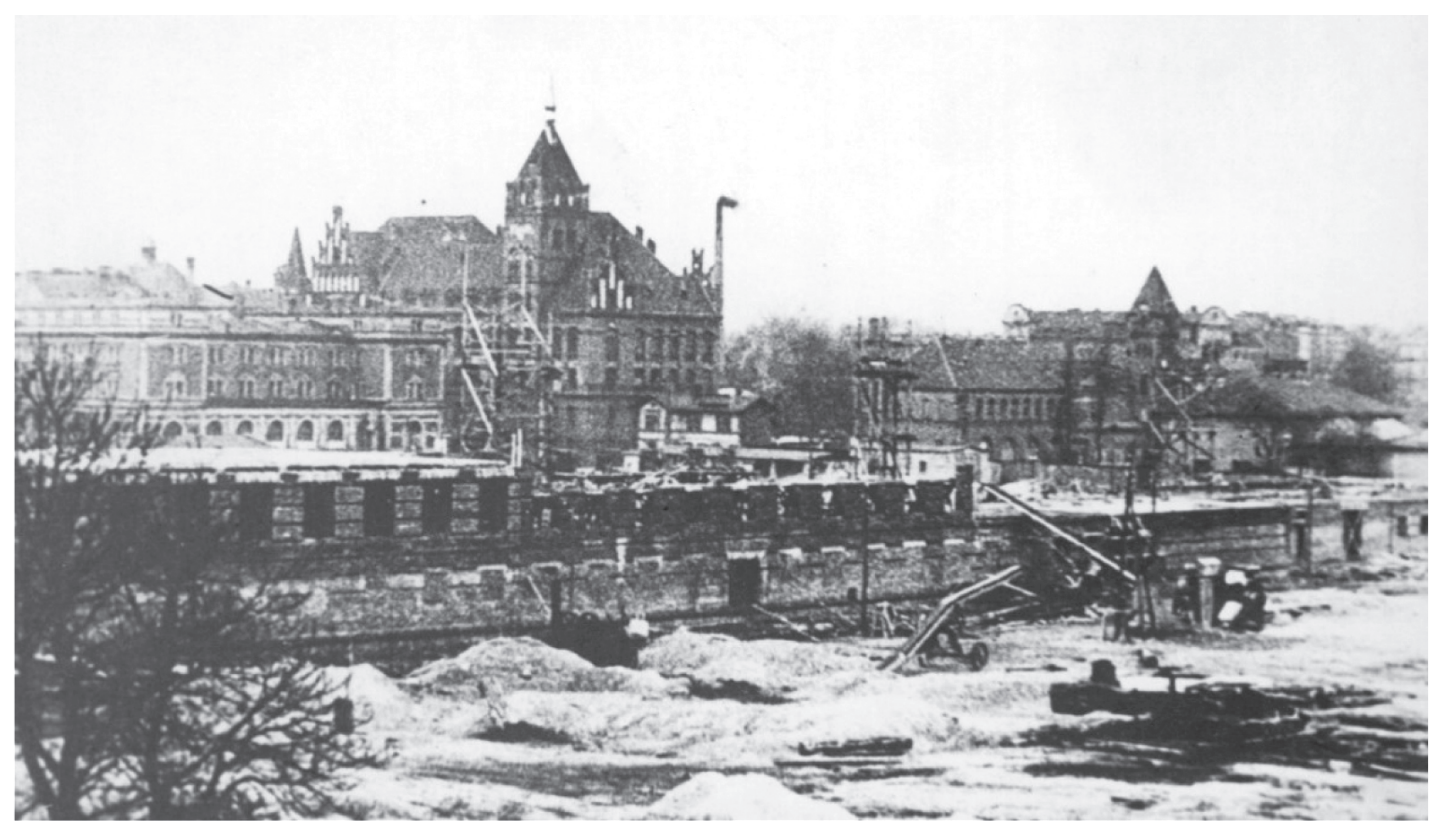

Fig. 2. Beginning of construction of the Faculty of Mining building (view of the Krakowski Square)

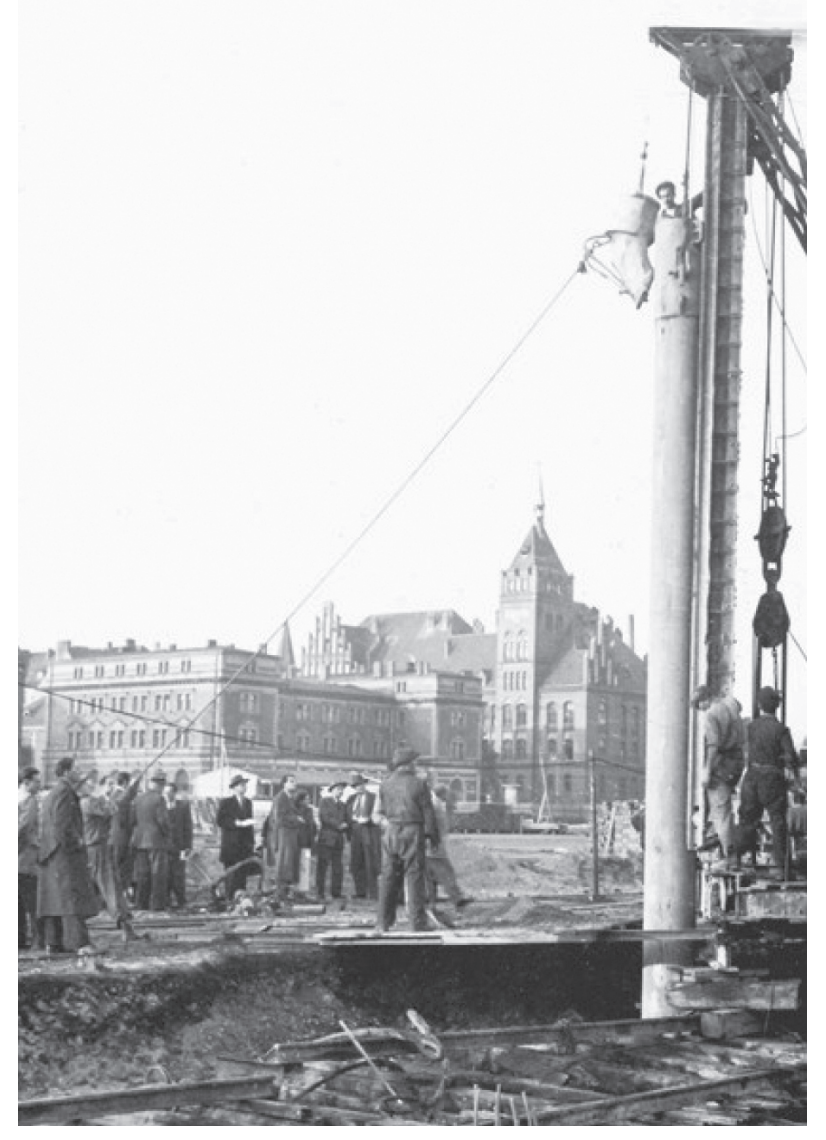

Fig. 3. Beginning of construction of the Faculty of Mining building - embedding of concrete piles

The name of the Faculty has also evolved. From the establishment of the Faculty from 1950 to 1991, the name of the Faculty of Mining was in operation. In 1991 the name was changed to the Faculty of Min- ing and Geology. Another name change took place in 2019 and the Faculty of Mining, Safety Engineering, and Industrial Automation has been in use since then.

The history of the Faculty is also the history of its Deans. They are presented chronologically below. Starting with prof. Józef Wąsowski (1950-1951), through: prof. Roman Dykacz (1952-1962); prof. Tadeusz Zarański (1962-1964); prof. Wacław Regulski (1964-1965); prof. Witold Parysiewicz (1965-1967); prof. Tadeusz Lasek (1967-1969); prof. Mirosław Chudek PhD (1970-1975) and (1985-1990); prof. Henryk Gil (1975-1981) and (1984-1985); prof. Włodzimierz Sikora (1981-1982), prof. Marian Kozdrój (1982-1984); prof. Bernard Drzęźla Ph.D. (1990-1996); prof. Marian Dolipski (1996-2002) and (2008-2016); prof. Krystian Probierz Ph.D. (2002-2008); ending with the current Dean, prof. Franciszek Plewa (2016-2020) and since 2020 [1-4].

\section{THE FACULTY TODAY}

Currently, scientific and research activities are carried out at the Faculty of Mining, Safety Engineering, and Industrial Automation (Fig. 4-6) in the field of sustainable mining, understood as the economically effective extraction of minerals, including advanced mining and information technologies. The Faculty develops knowledge in the field of obtaining raw materials in environmentally friendly conditions, for 
the purposes of rational resource management consisting of the supply of raw materials in sufficient quantity for the efficient operation of the national economy. These activities are also related to: mechanisation, automation, and robotisation of mining processes; minimising interference to the environment during the exploration and exploitation of mineral deposits; protection of unexploited and exploited mineral deposits by the maximum use of the deposit resources; the use of mineral resources in waste from mining and processes of mineral enrichment; and minimisation of the generated waste.

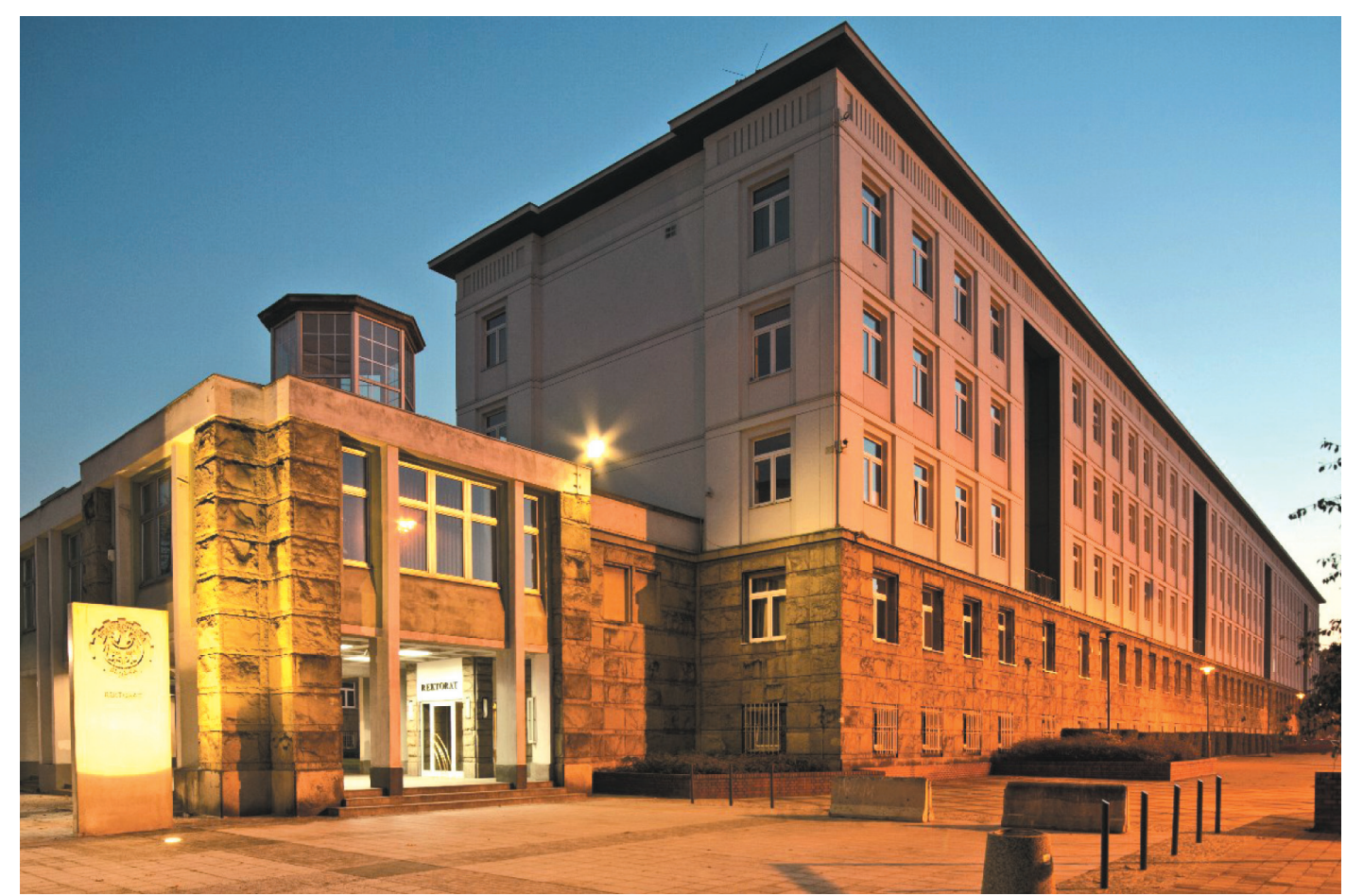

Fig. 4. View of the Faculty of Mining, Safety Engineering, and Industrial Automation (from the Rector's Office)

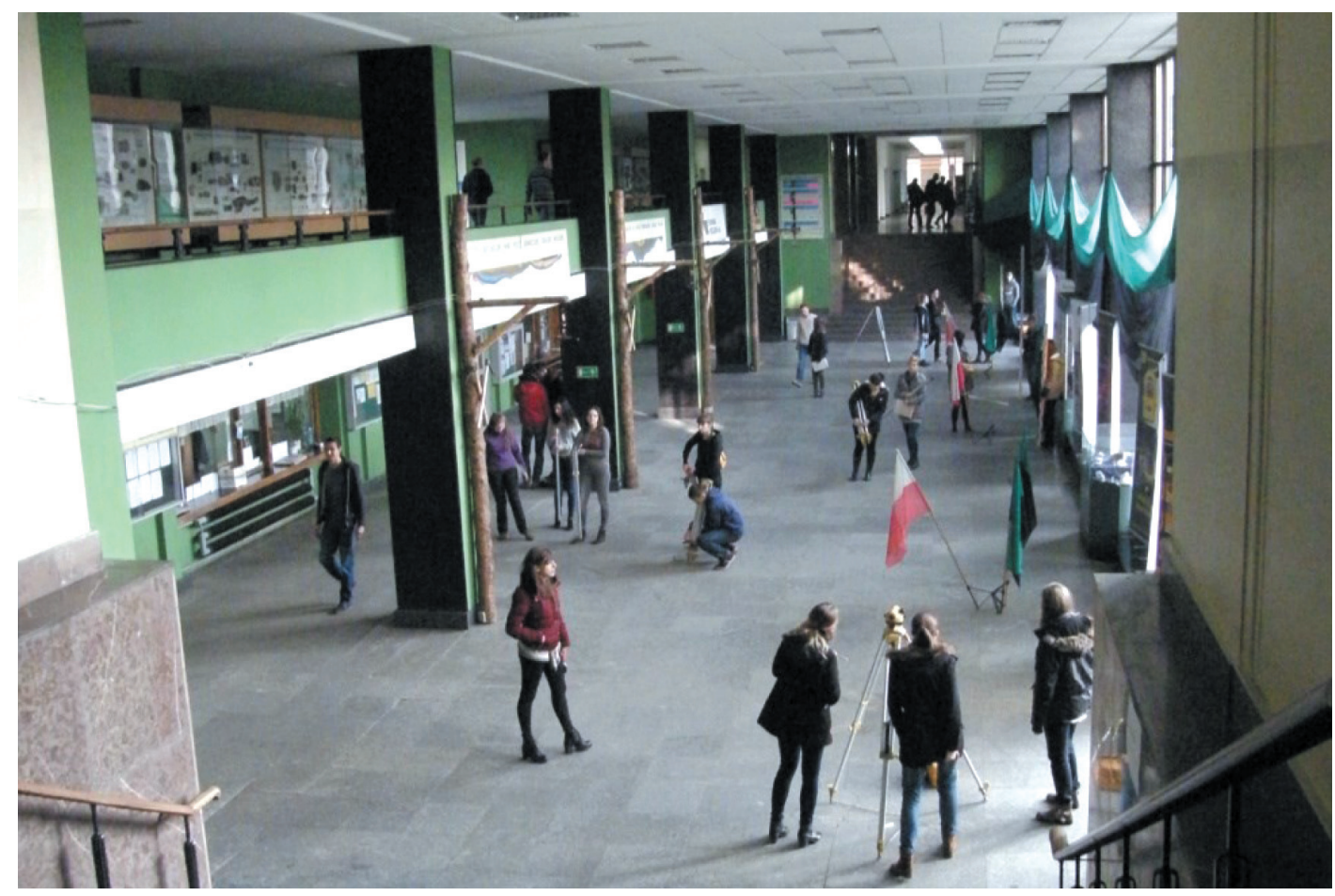

Fig. 5. View of the main hall of the Faculty 


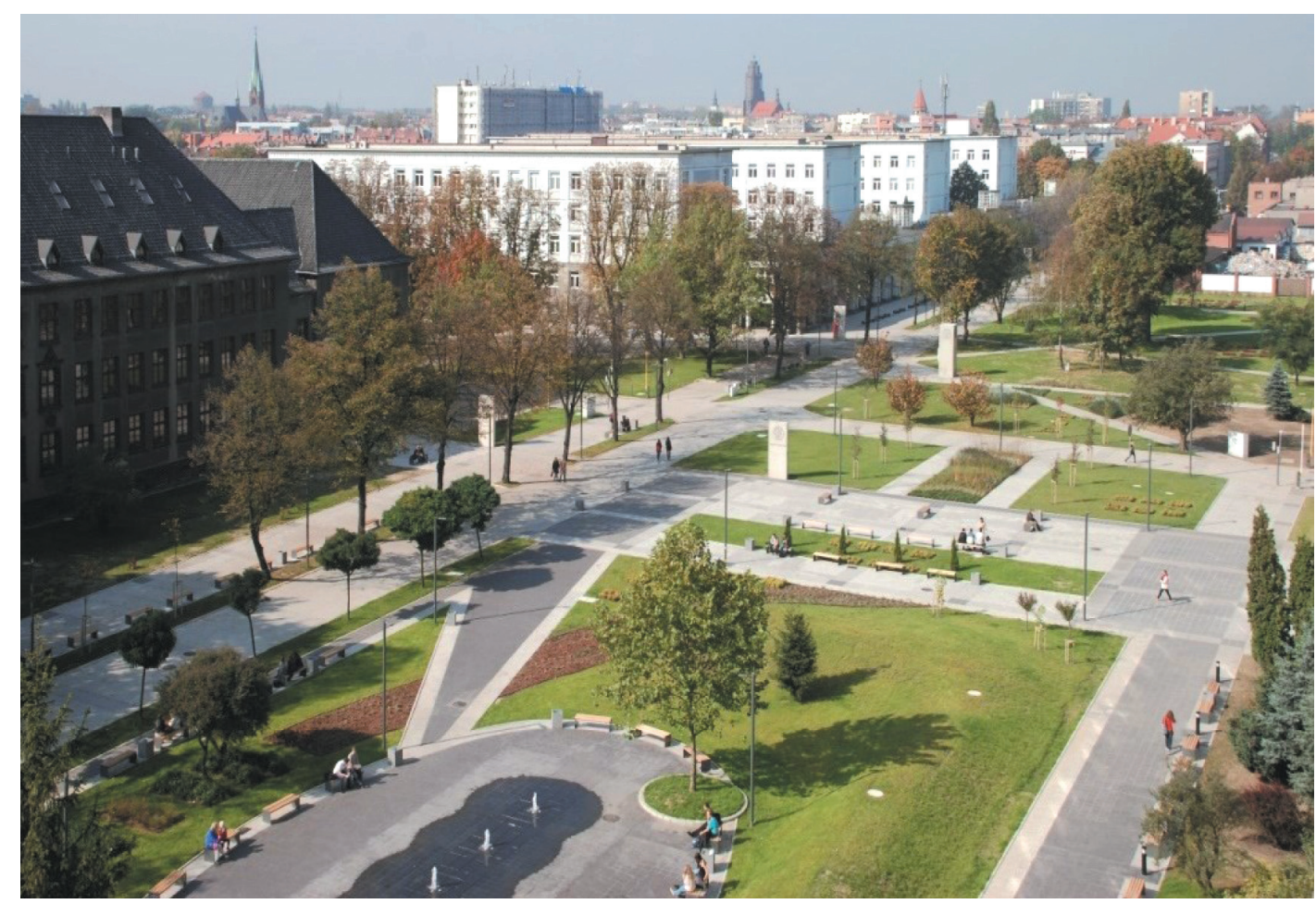

Fig. 6. General view of the Gliwice Campus and the Faculty of Mining, Safety Engineering, and Industrial Automation

The department also deals with issues of safety engineering, in particular the issues of public safety, occupational health and safety and fire protection, crisis management and cyber-security, as well as issues related to broadly understood automation and industrial IT, and electrical engineering and automation in mining.

The Faculty's research and teaching activities are currently focused on six departments, namely: Electrical Engineering and Industrial Automation, Mining Mechanisation and Robotisation, Safety Engineering, Geomechanics and Underground Construction, Mining, and Applied Geology.

The authorities at the Faculty currently include: the Dean of the Faculty - prof. Franciszek Plewa; Vice-Dean for Cooperation and Development prof. Iwona Jonczy; Vice-Dean for Infrastructure and Organisation - prof. Krzysztof Filipowicz; Vice-Dean for Education - prof. Małgorzata Wyganowska.

The Faculty of Mining, Safety Engineering, and Industrial Automation is a forge of human resources for modern industry. It offers education for students in the form of $1^{\text {st }}$ degree studies, $2^{\text {nd }}$ degree studies, both full-time and extramural, and the education of Ph.D. students in the form of $3^{\text {rd }}$ degree studies.
Education takes place in five programmes:

- Automatic Control and Industrial Informatics,

- Geodesy and Cartography,

- Geoengineering and Raw Materials Extraction,

- Safety Engineering,

- Reclamation and Management of Post-industrial Areas.

All study plans are adapted to European standards, based on the credit point system - ECTS (European Credit Transfer System), which allows students to complete part of their studies abroad.

There are active Student Scientific Clubs at the Faculty. Within the Clubs, students can pursue their interests related to the specialisation they are studying. The "Agrimensor," "Bezpieczna Ściana," "Bezpiecznik," "El-Carbo," "Gwarek," "Konstrukcja i Eksploatacja Maszyn," "Przeróbka Kopalin Stałych," and "Silesian" Clubs participate in the Faculty's annual Scientific Club Conference, organise scientific trips, conferences, and seminars. The Science Clubs and Faculty staff actively participate in the cyclically organised Scientists' Night, which includes multimedia shows, laboratories, and lectures in various fields of science for children, adolescents, and adults. Students of the "Bezpieczna Ściana" ("Safe Wall") science club regular take first place in mining knowledge competitions organised annually in Krakow. 
The Faculty of Mining, Safety Engineering, and Industrial Automation actively cooperates with schools in order to popularise technical education. We are happy to meet young people, we conduct popular science lectures in the "KNOWLEDGE $\rightarrow$ TECHNOLOGY $\rightarrow$ CAREER" series, in the field of, among others, mechatronics, electronics, mineral exploitation, geology, geodesy, and safety. We are open to visits by students at our Faculty, we make our laboratories available, we encourage everyone to visit the Museum of Deposit Geology and the Technology Hall.

For many years, the Faculty has been intensively cooperating with many companies active in the mining industry and other sectors of the national economy. The cooperation includes, among others, organisation of student internships and apprenticeships, joint research and development projects.

The Faculty's activities are supported by the Social and Program Council, which is an advisory body expressing opinions on the quality of education and assessing the degree and adaptability of the Faculty's graduates in their workplaces. The Social and Program Council also aims to analyse the state and create conditions for fostering direct connections between the scientific community and workplaces, regional authorities, industry institutes, and educational institutions.

Every year, the Faculty hosts cyclical Minerals Fairs, as well as scientific and technical conferences and seminars. In December, during St. Barbara's Day Celebrations, the St. Barbara's Day Academy and Beer Feast take place.

These examples of such a broad activity of the Faculty of Mining, Safety Engineering, and Industrial Automation demonstrate the great commitment of the scientific and research staff as well as administrative and technical employees in its development, in improving their skills, in acquiring scientific knowledge, and at the same time in educating young engineers, emphasising the importance and the accuracy of the decision which led to its establishment 70 years ago.

\section{References}

[1] 40-lecie Wydziatu Górniczego i spis absolwentów, Wydawnictwo Politechniki Śląskiej, Gliwice 1990.

[2] Kronika Wydziału Górnictwa i Geologii 1950-2000, red. K. Probierz, Wydawnictwo Politechniki Śląskiej, Gliwice 2000.

[3] Wydziat Górnictwa i Geologii 1950-2005, red. K. Probierz, Wydawnictwo Politechniki Śląskiej, Gliwice 2006.

[4] Materials of Faculty of Mining, Safety Engineering, and Industrial Automation.

FRANCISZEK PLEWA, Prof. Ph.D., D.Sc., Eng. IWONA JONCZY, Ph.D., D.Sc., Eng. KRZYSZTOF FILIPOWICZ, Ph.D., D.Sc., Eng.

Silesian University of Technology Faculty of Mining, Safety Engineering and Industrial Automation

ul. Akademicka 2, 44-100 Gliwice, Poland iwona.jonczy@polsl.pl

(C) 2020 Authors. This is an open access publication, which can be used, distributed, and reproduced in any medium according to the Creative Commons CC-BY 4.0 License. 


\title{
70 lat Wydziału Górnictwa, Inżynierii Bezpieczeństwa i Automatyki Przemysłowej Politechniki Śląskiej w Gliwicach
}

\begin{abstract}
12 lipca 1950 roku, zgodnie z Rozporzadzeniem Ministra Szkót Wyższych, na Politechnice Ślaskiej w Gliwicach utworzono Wydziat Górniczy. Określenie zadań i programów nauczania, skompletowanie kadry naukowej, pozyskanie studentów oraz prace zwiqzane z przygotowaniem nowych pomieszczeń i rozbudowa infrastruktury, stanowity pierwsze wyzwania dla nowo utworzonego wydziału. W miarę uplywu czasu ewoluowała również nazwa wydziału - od 2019 roku funkcjonuje Wydziat Górnictwa, Inżynierii Bezpieczeństwa i Automatyki Przemystowej.
\end{abstract}

Słowa kluczowe: Wydział Górnictwa, Inżynierii Bezpieczeństwa i Automatyki Przemystowej, Gliwice

\section{WPROWADZENIE}

Zgodnie z Rozporządzeniem Ministra Szkót Wyższych $i$ Nauki z dnia 12 lipca 1950 roku $w$ sprawie zmian organizacyjnych $w$ niektórych szkołach wyższych, na podstawie dekretu z dnia 28 października 1947 roku o organizacji nauki i szkolnictwa wyższego, na Politechnice Śląskiej w Gliwicach w roku 1950 utworzono Wydział Górniczy (rys. 1).
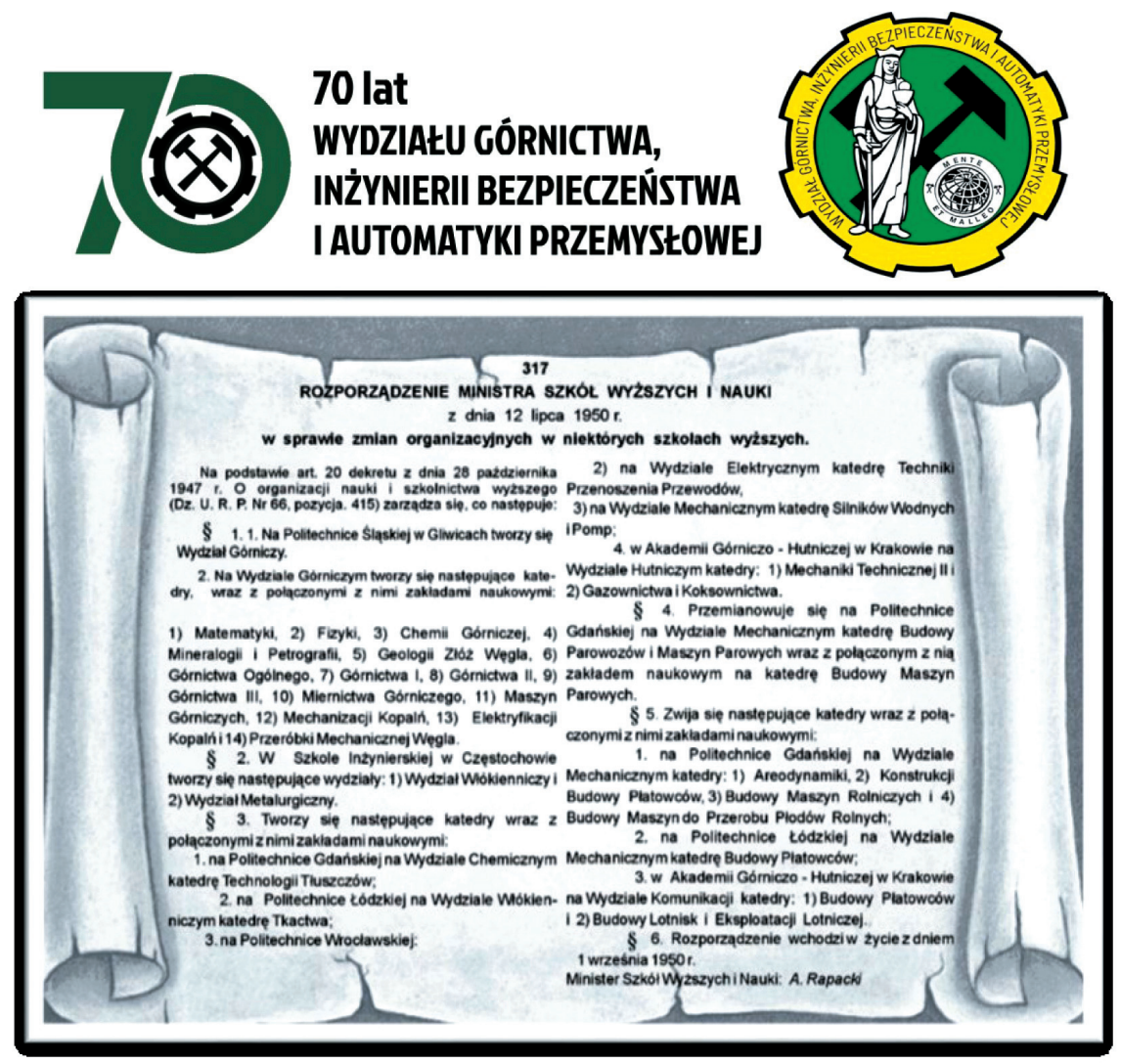

Rys. 1. Rozporządzenie Ministra Szkót Wyższych i Nauki z dnia 12 lipca 1950 roku o utworzeniu Wydziału Górniczego 
Powołanie do istnienia wydziału i tym samym studiów górniczych było uwarunkowane określeniem zadań i programów nauczania dla wszystkich lat studiów, na tej podstawie zaproponowano obciążenie dydaktyczne dla poszczególnych jednostek wewnętrznych wydziału, którymi były wtedy katedry i zakłady. Wymagało to uzgodnienia programu studiów górniczych na Politechnice Śląskiej z programami Akademii Górniczo-Hutniczej oraz Politechniki Wrocławskiej, w której miał powstać Wydział Górniczy wyspecjalizowany w eksploatacji złóż węgla brunatnego. W tym celu powołano Komisję Studiów Programowych, która ustaliła ramowe i szczegółowe programy studiów inżynierskich na Wydziałach Górniczych. W połowie czerwca 1950 roku uzyskano więc podstawę do wystąpienia Rektora Politechniki Śląskiej do Ministra o powołanie Studiów Górniczych w Politechnice Śląskiej [1].

\section{HISTORIA WYDZIAŁU}

Akt erekcyjny wydziału został podpisany 12 lipca 1950 roku. Przygotowanie aktu trwało cztery miesiące, jednak Ministerstwo przyspieszyło działania i przed zakończeniem procedur administracyjnych wyrażono zgodę na powołanie $\mathrm{z}$ dniem 1 lipca 1950 roku Dziekanatu Wydziału Górniczego i powierzenie funkcji p.o. dziekana prof. dr. Józefowi Wąsowskiemu.

Kluczowym wyzwaniem było jednak pozyskanie studentów oraz kadry. Władze akademickie we współpracy z organizacjami studenckimi oraz z Departamentem Szkolnictwa Zawodowego Ministerstwa Górnictwa zorganizowały bezpłatny kurs „Górnictwa ogólnego" dla studentów i pracowników Politechniki Śląskiej, którzy mieli w przyszłości zostać potencjalnymi pracownikami nowo utworzonego wydziału. Kurs rozpoczął się 10 lipca wykładem inauguracyjnym „Górnictwo w Polsce. Geologia polskich zagłębi węglowych" i trwał do 19 lipca, obejmując wykłady, seminaria i zajęcia praktyczne z górnictwa.

Pozyskiwanie kadry naukowej przebiegało stopniowo, w miarę wzrastania liczby zajęć dydaktycznych, i dopiero w latach 1954-1956 wydział wszedł w już ustalony tryb pracy. Dziekanem był wówczas prof. mgr inż. Roman Dykacz. Ponad 70\% stanowisk kierowników katedr objęli wychowankowie Akademii Górniczo-Hutniczej, ale nie można również pominąć związków z Uniwersytetem Jagiellońskim, którego pierwszym profesorem mineralogii i petrografii był Jan Kühl.
Jednocześnie z rozpoczęciem działalności dydaktycznej wydziału prowadzono prace organizacyjne mające na celu włączenie do struktury Wydziału Górniczego grup studenckich specjalności górniczych, kształcących się na Wydziale Mechanicznym i Wydziale Elektrycznym. Ostatecznie słuchacze tych wydziałów zostali przeniesieni na Wydział Górniczy w roku akademickim 1951/1952. W 1951 roku na wydziale została również obroniona pierwsza praca doktorska (przez doc. Czesława Poborskiego).

Budynek Wydziału Górniczego postanowiono wznieść w miejscu, w którym jeszcze pól wieku temu znajdował się duży zbiornik wodny - staw, będący pamiątką po rozlewiskach przepływającej niedaleko Kłodnicy. Obiekt stanął na kilkuset palach żelbetowych sięgających bardziej zwięzłego gruntu (rys. 2 i 3).

Istotne dla funkcjonowania struktury wydziału było uzyskanie pomieszczeń na jego lokalizację. W lipcu 1950 roku Ministerstwo Górnictwa przekazało gmach znajdujący się na rynku w Gliwicach, w którym utworzono dziekanat Wydziału Górniczego oraz dom studencki. W grudniu 1952 roku do dyspozycji studentów i pracowników przekazano dwa pierwsze segmenty nowo powstającego Wydziału Górniczego przy placu Krakowskim. Okres intensywnej rozbudowy obecnej siedziby wydziału nastąpił w latach 1952-1955, co związane było z zapotrzebowaniem resortu górnictwa na wysoko wykwalifikowaną kadrę inżynierską. Zaowocowało to powołaniem w 1954 roku studiów zaocznych I stopnia, a w 1955 roku wieczorowego studium zawodowego. Ranga wydziału systematycznie wzrastała, tak że w 1958 roku Ministerstwo Górnictwa zorganizowało na nim Międzynarodową Wystawę Budownictwa Kopalń. W 1959 roku oddano do użytkowania halę technologiczną wydziału.

Kolejne działania na rzecz rozwoju wydziału były związane z powołaniem jego dwóch filii - w Rybniku oraz Dąbrowie Górniczej.

$\mathrm{Na}$ wydziale w początkowym okresie jego funkcjonowania istniało siedemnaście katedr, w latach 60 . i 70. XX wieku było ich dziewiętnaście, natomiast reorganizacja struktury wydziału w 1969 roku doprowadziła do utworzenia ośmiu katedr jako dużych jednostek naukowo-dydaktycznych złożonych $\mathrm{z}$ poprzednich mniejszych katedr. Dwie spośród nich, tj. Katedrę Matematyki C oraz Katedrę Chemii Ogólnej, odłączono od wydziału. W 1972 roku przeprowadzono kolejną reorganizację, która spowodowała zmniejszenie liczby katedr do sześciu, które z kolei dały początek siedmiu instytutom badawczo-dydaktycznym. Obecnie na wydziale funkcjonuje sześć katedr. 


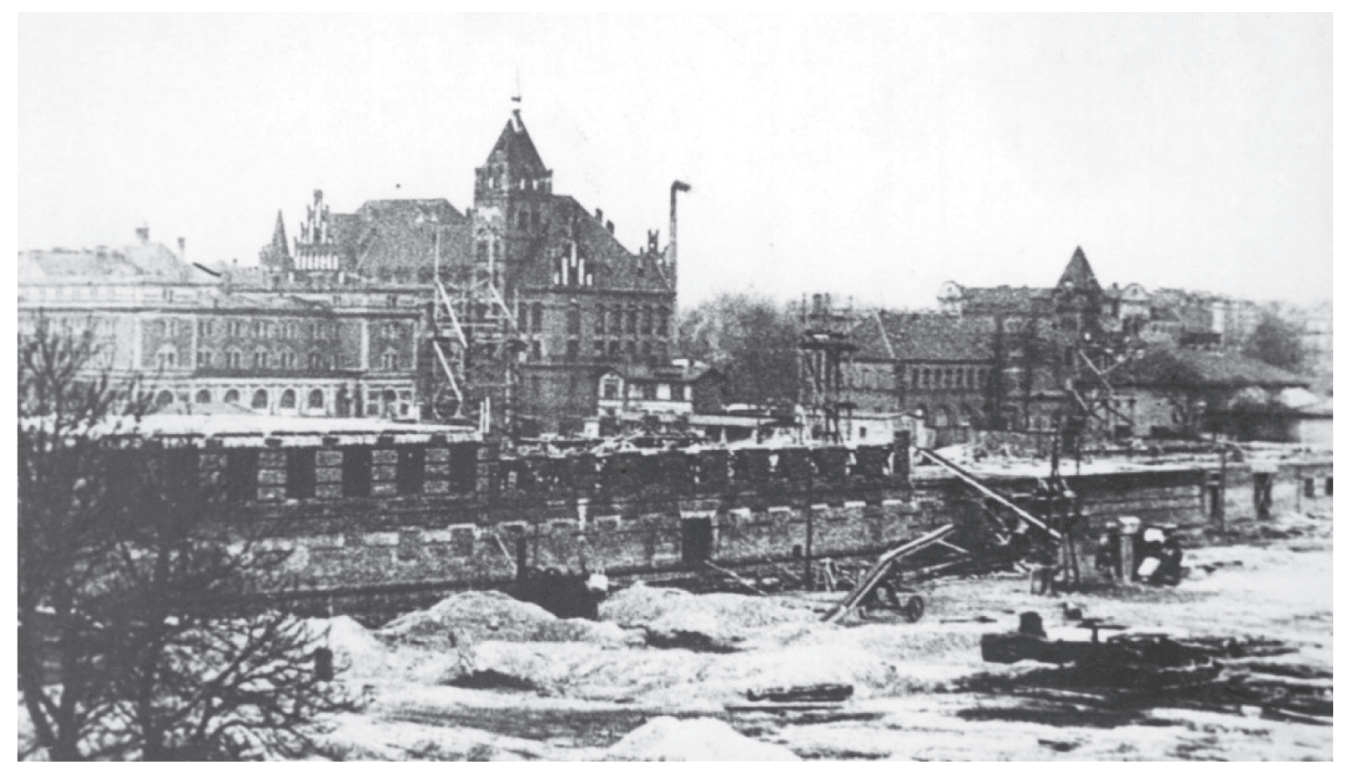

Rys. 2. Budowa siedziby Wydziału Górniczego (widok na plac Krakowski)

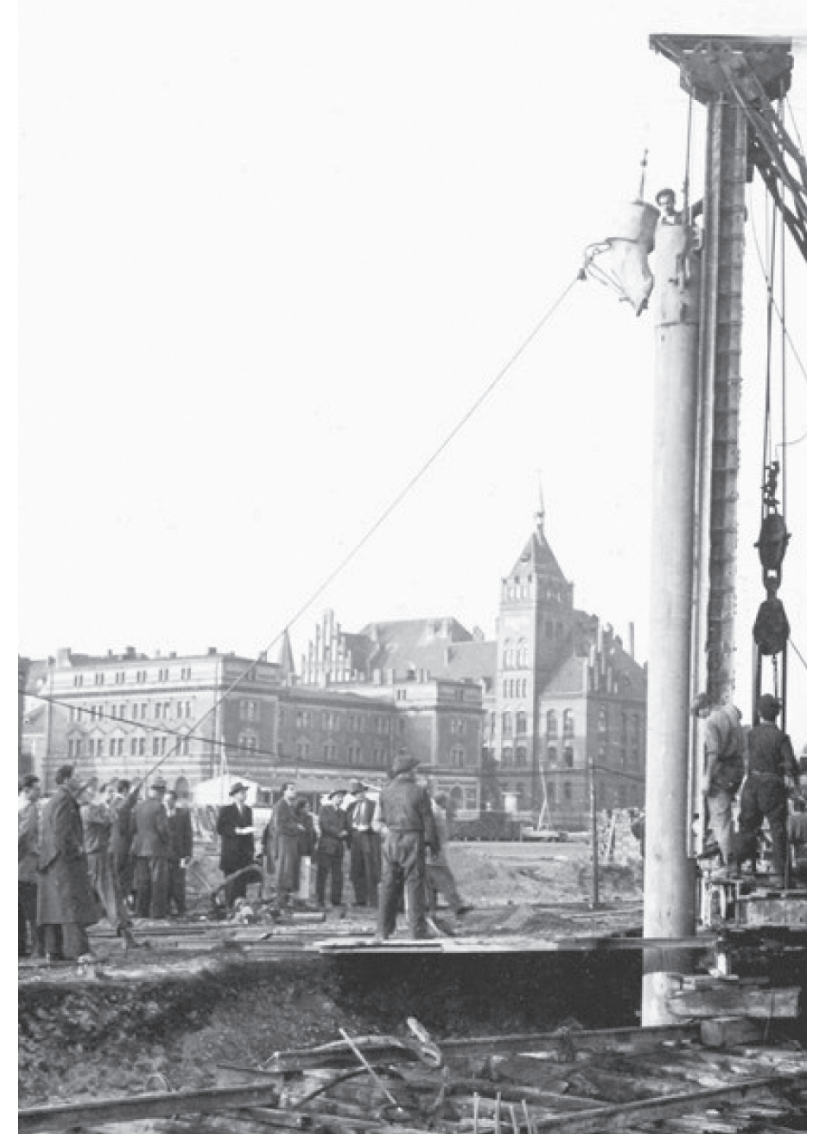

Rys. 3. Poczatek budowy siedziby

Wydziału Górniczego - osadzanie betonowych pali

Modyfikacjom ulegała również nazwa wydziału. Od jego powstania w 1950 roku do 1991 roku funkcjonowała nazwa Wydział Górniczy. W 1991 roku zmieniono ją na Wydział Górnictwa i Geologii. Kolejna zmiana nazwy nastąpiła w 2019 roku i od tego czasu funkcjonuje Wydział Górnictwa, Inżynierii Bezpieczeństwa i Automatyki Przemysłowej.

Historia wydziału to również historia jego dziekanów. Według chronologii byli nimi: prof. dr inż. Józef Wąsowski (1950-1951), prof. mgr inż. Roman Dykacz (1952-1962), prof. dr inż. Tadeusz Zarański (19621964), prof. mgr inż. Wacław Regulski (1964-1965), prof. dr inż. Witold Parysiewicz (1965-1967), prof. mgr inż. Tadeusz Lasek (1967-1969), prof. zw. dr hab. inż. Mirosław Chudek dr h.c. (1970-1975) i (19851990), prof. dr hab. inż. Henryk Gil (1975-1981) i (1984-1985), prof. dr inż. Włodzimierz Sikora (1981-1982), prof. zw. dr hab. inż. Marian Kozdrój (1982-1984), prof. dr hab. inż. Bernard Drzęźla dr h.c. (1990-1996), prof. dr hab. inż. Marian Dolipski (1996-2002) i (2008-2016), prof. dr hab. inż. Krystian Probierz dr h.c. (2002-2008), prof. dr hab. inż. Franciszek Plewa (2016-2020 i od 2020 roku) do dziś [1-4].

\section{WYDZIAK OBECNIE}

Obecnie na Wydziale Górnictwa, Inżynierii Bezpieczeństwa i Automatyki Przemysłowej (rys. 4-6) prowadzona jest działalność naukowo-badawcza w zakresie górnictwa zrównoważonego rozwoju rozumianego jako ekonomicznie efektywne wydobywanie kopalin z uwzględnieniem zaawansowanych technologii górniczych i informatycznych. Wydział kształtuje wiedzę w zakresie pozyskiwania surowców w warunkach przyjaznych środowisku na potrzeby prowadzenia racjonalnej gospodarki złożowo-surowcowej polegającej 
na dostarczeniu surowców w ilości wystarczającej do sprawnego działania gospodarki krajowej. Działalność ta związana jest również z mechanizacją, automatyzacją i robotyzacją procesów wydobywczych, minimalizacją ingerencji w środowisko w czasie poszukiwań i eksploatacji złóż kopalin, ochroną nieek- sploatowanych i eksploatowanych złóż kopalin przez maksymalne wykorzystanie zasobów złoża, wykorzystaniem surowców mineralnych znajdujących się w odpadach powstałych po robotach górniczych i procesach wzbogacania kopalin oraz minimalizacją powstających odpadów.

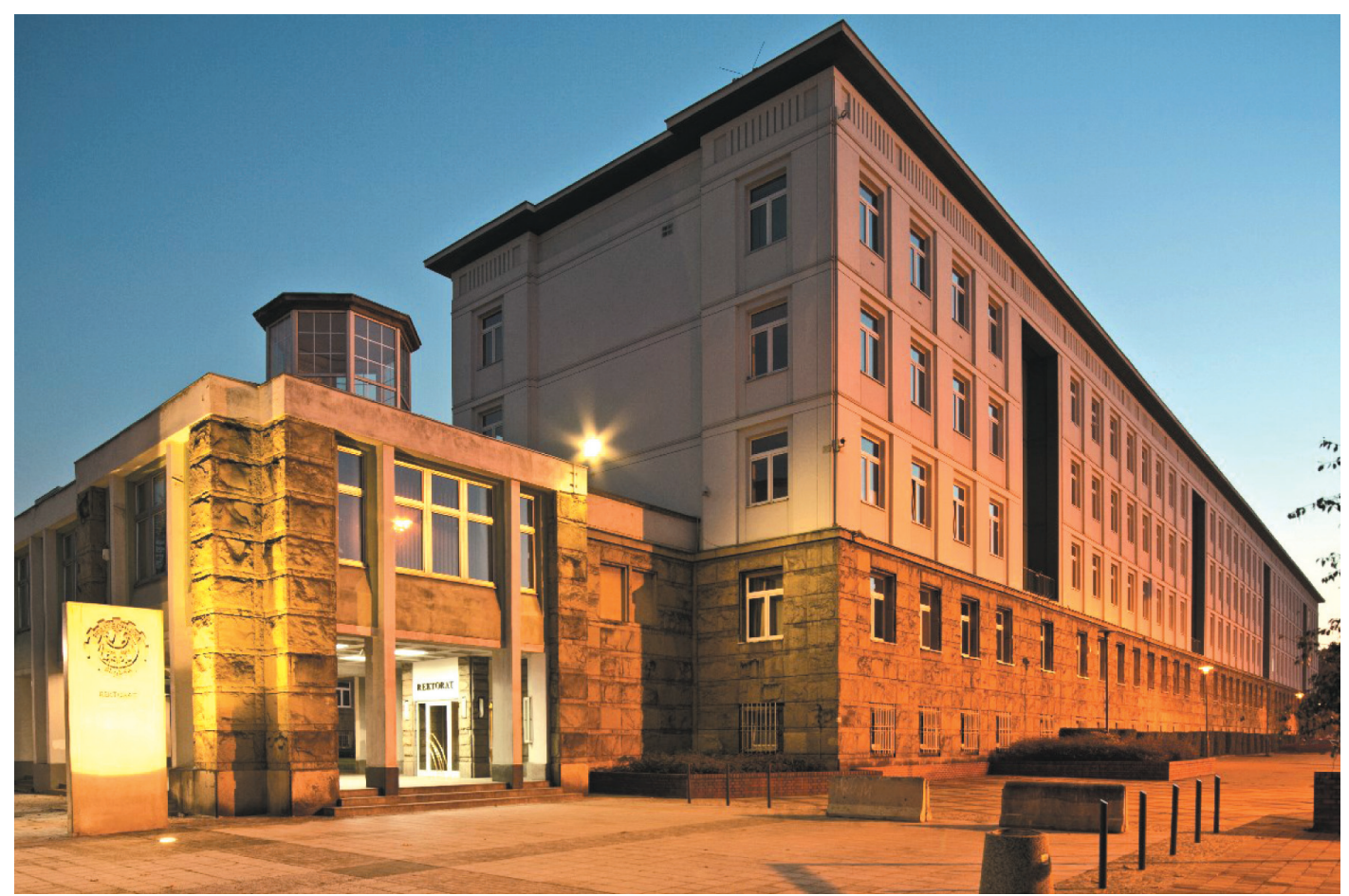

Rys. 4. Budynek Wydziału Górnictwa, Inżynierii Bezpieczeństwa i Automatyki Przemystowej (widok od strony Rektoratu)

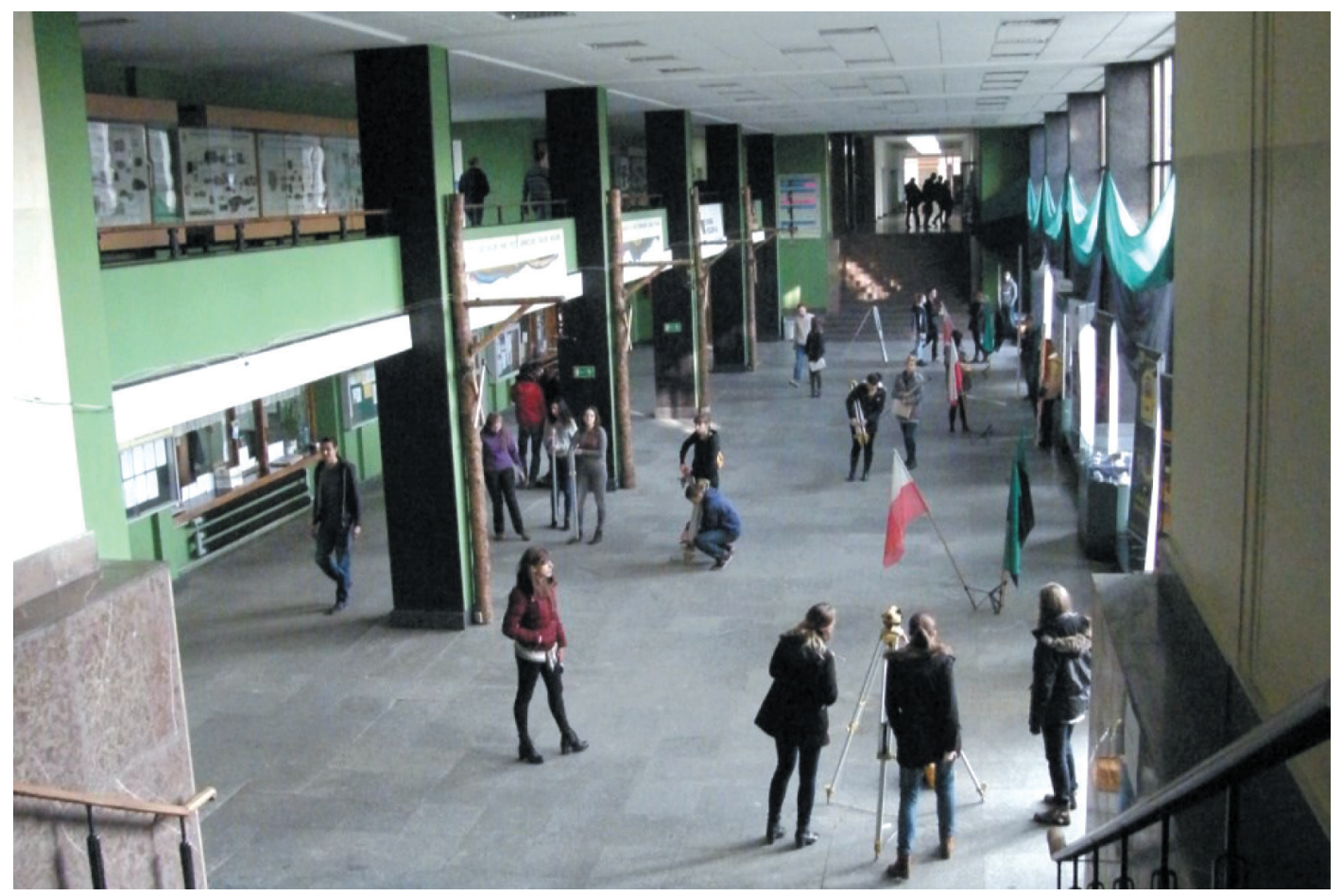

Rys. 5. Widok holu głównego wydziału 


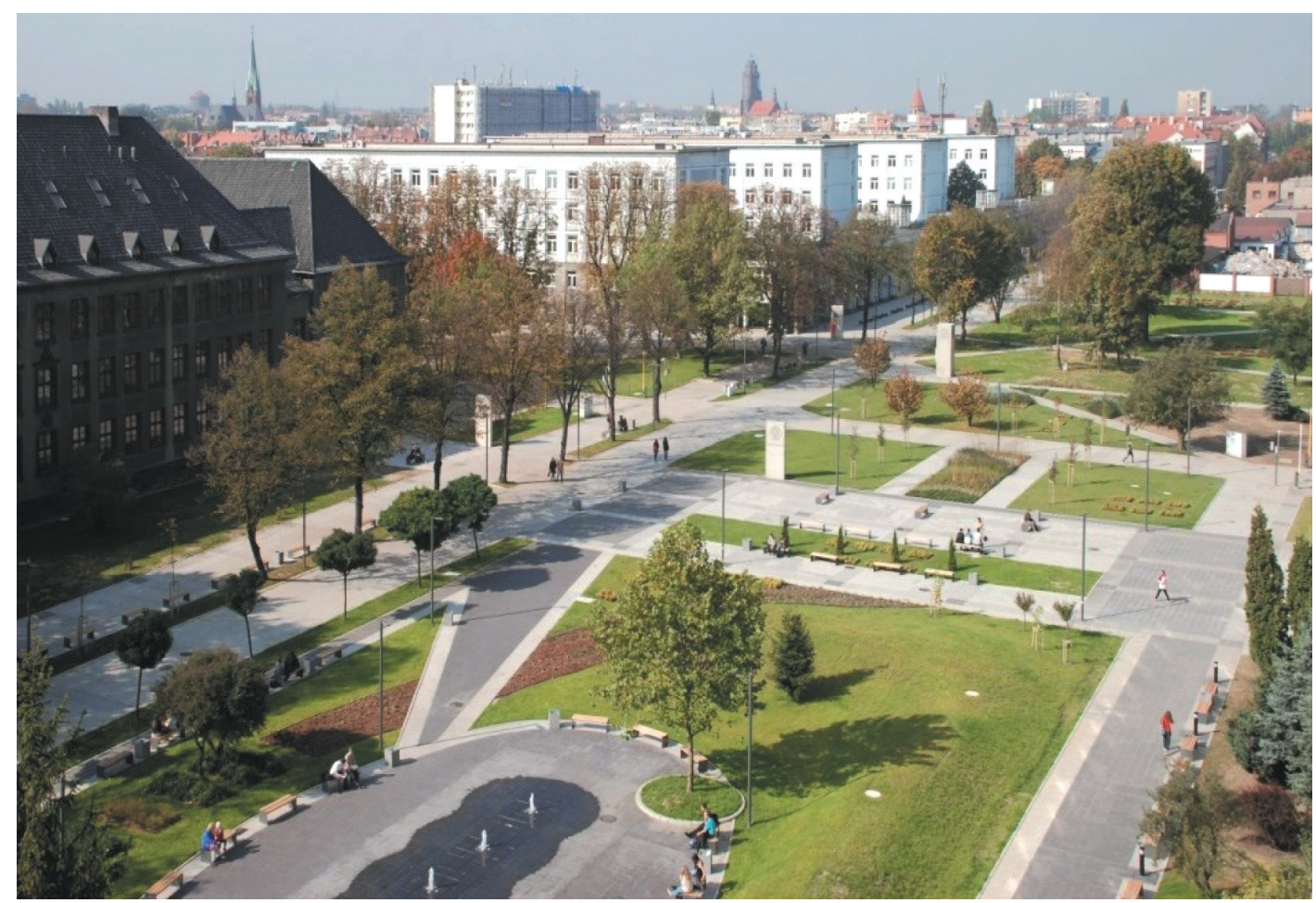

Rys. 6. Widok ogólny na Kampus Gliwice i Wydziat Górnictwa, Inżynierii Bezpieczeństwa i Automatyki Przemystowej

Wydział zajmuje się również problematyką inżynierii bezpieczeństwa, w szczególności zagadnieniami bezpieczeństwa publicznego, BHP i ochroną przeciwpożarową, zarządzaniem kryzysowym i cyberbezpieczeństwem oraz problematyką związaną z szeroko rozumianą automatyką i informatyką przemysłową, jak również elektrotechniką i automatyką w górnictwie.

Działalność naukowa i dydaktyczna wydziału skupiona jest obecnie w sześciu katedrach, mianowicie: Katedrze Elektrotechniki i Automatyki Przemysłowej, Katedrze Mechanizacji i Robotyzacji Górnictwa, Katedrze Geomechaniki i Budownictwa Podziemnego, Katedrze Eksploatacji Złóż oraz Katedrze Geologii Stosowanej.

Władze wydziału stanowią obecnie: dziekan prof. dr hab. inż. Franciszek Plewa, prodziekan ds. współpracy i rozwoju dr hab. inż. Iwona Jonczy, prof. PŚ, prodziekan ds. infrastruktury i organizacji dr hab. inż. Krzysztof Filipowicz, prof. PŚ, prodziekan ds. kształcenia dr hab. inż. Małgorzata Wyganowska, prof. PŚ.

Wydział Górnictwa, Inżynierii Bezpieczeństwa i Automatyki to kuźnia kadr dla nowoczesnego przemysłu. Oferuje się na nim kształcenie studentów na studiach I stopnia inżynierskich, II stopnia magisterskich, zarówno w systemie stacjonarnym, jak i niestacjonarnym, oraz kształcenie doktorantów na stu- diach III stopnia. Kształcenie odbywa się na pięciu kierunkach:

- Automatyka i Informatyka Przemysłowa,

- Geodezja i Kartografia,

- Geoinżynieria i Eksploatacja Surowców,

- Inżynieria Bezpieczeństwa,

- Rekultywacja i Zagospodarowanie Terenów Poprzemysłowych.

Wszystkie plany studiów dostosowane są do standardów europejskich, opierają się na systemie punktów kredytowych ECTS (ang. European Credit Transfer System), co umożliwia odbywanie części studiów za granicą.

$\mathrm{Na}$ wydziale aktywnie działają studenckie koła naukowe, w których studenci mogą realizować swoje zainteresowania związane ze studiowaną specjalnością. Koła Agrimensor, Bezpieczna Ściana, Bezpiecznik, El-Carbo, Gwarek, Konstrukcja i Eksploatacja Maszyn, Przeróbka Kopalin Stałych oraz Silesian co roku uczestniczą w Konferencji Kół Naukowych Wydziału, organizują wyjazdy naukowe, konferencje i seminaria. Członkowie kół naukowych oraz pracownicy wydziału aktywnie uczestniczą w cyklicznie organizowanej Nocy Naukowców, w ramach której odbywają się pokazy multimedialne, laboratoria i wykłady z różnych dziedzin nauki kierowane do dzieci, młodzieży 
i dorosłych. Studenci koła naukowego Bezpieczna Ściana zajmują pierwsze miejsca w konkursach wiedzy górniczej organizowanych corocznie w Krakowie.

Wydział Górnictwa, Inżynierii Bezpieczeństwa i Automatyki Przemysłowej aktywnie współpracuje ze szkołami w celu popularyzacji kształcenia technicznego. Chętnie spotykamy się z młodzieżą, prowadzimy wykłady popularnonaukowe w cyklu „WIEDZA $\rightarrow$ TECHNIKA $\rightarrow$ KARIERA", z zakresu m.in. mechatroniki, elektroniki, eksploatacji surowców mineralnych, geologii, geodezji i bezpieczeństwa. Jesteśmy otwarci na wizyty uczniów na naszym wydziale, udostępniamy nasze laboratoria, zachęcamy do odwiedzenia Muzeum Geologii Złóż oraz Hali Technologicznej.

Wydział od wielu lat intensywnie współpracuje z wieloma firmami działającymi w przemyśle górniczym i innych branżach gospodarki narodowej. Współpraca obejmuje m.in. organizację staży i praktyk studenckich, wspólne projekty i prace naukowo-badawcze.

Działalność wydziału wspierana jest przez Radę Społeczno-Programową stanowiącą organ doradczy, wyrażający opinie dotyczące jakości kształcenia oraz oceniający stopień i zdolności adaptacji absolwentów wydziału w miejscach pracy. Rada Społeczno-Programowa ma również na celu analizowanie stanu i tworzenie warunków do bezpośredniego powiązania środowiska naukowego z zakładami pracy, władzami regionu, instytutami branżowymi i placówkami oświatowymi.

Corocznie na wydziale odbywają się giełdy minerałów oraz konferencje i seminaria naukowo-techniczne, a w grudniu podczas uroczystości barbórkowych organizowana jest Akademia Barbórkowa połączona z Biesiadą Piwną.

Wymienione przykłady szerokiej działalności Wydziału Górnictwa, Inżynierii Bezpieczeństwa i Automatyki Przemysłowej świadczą o dużym zaangażowaniu kadry naukowo-badawczej, pracowników administracyjnych i technicznych w jego rozwój, w doskonalenie swoich umiejętności, w zdobywanie wiedzy naukowej, a zarazem w kształcenie młodych kadr inżynierów, podkreślając ważność i trafność decyzji o jego powołaniu siedemdziesiąt lat temu.

\section{Literatura}

[1] 40-lecie Wydziału Górniczego i spis absolwentów, Wydawnictwo Politechniki Śląskiej, Gliwice 1990.

[2] Kronika Wydziatu Górnictwa i Geologii 1950-2000, red. K. Probierz, Wydawnictwo Politechniki Ślaskiej, Gliwice 2000.

[3] Wydziat Górnictwa i Geologii 1950-2005, red. K. Probierz, Wydawnictwo Politechniki Śląskiej, Gliwice 2006.

[4] Materiały własne Wydziału Górnictwa, Inżynierii Bezpieczeństwa i Automatyki Przemysłowej Politechniki Śląskiej.

prof. dr hab. inż. FRANCISZEK PLEWA dr hab. inż. IWONA JONCZY, prof. PŚ dr hab. inż. KRZYSZTOF FILIPOWICZ, prof. PŚ Politechnika Ślaska Wydziat Górnictwa, Inżynierii Bezpieczeństwa i Automatyki Przemystowej ul. Akademicka 2, 44-100 Gliwice iwona.jonczy@polsl.pl 